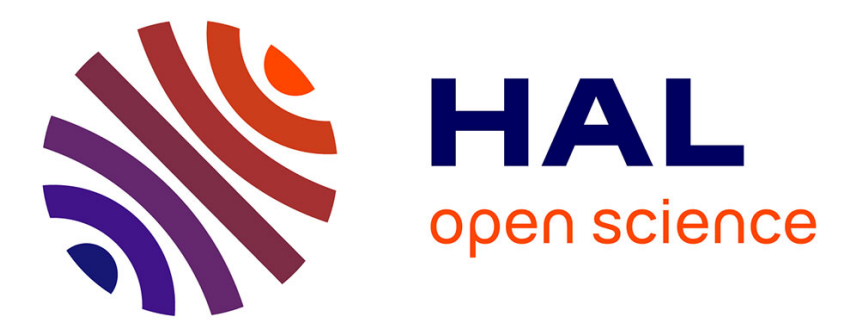

\title{
The French defence industry in the knowledge management era: A historical overview and evidence from empirical data
}

Sarah Guillou, Nathalie Lazaric, Christian Longhi, Sylvie Rochhia

\section{- To cite this version:}

Sarah Guillou, Nathalie Lazaric, Christian Longhi, Sylvie Rochhia. The French defence industry in the knowledge management era: A historical overview and evidence from empirical data. Research Policy, 2009, 38 (1), pp.170-180. hal-00457550

\author{
HAL Id: hal-00457550 \\ https://hal.science/hal-00457550
}

Submitted on 23 Feb 2010

HAL is a multi-disciplinary open access archive for the deposit and dissemination of scientific research documents, whether they are published or not. The documents may come from teaching and research institutions in France or abroad, or from public or private research centers.
L'archive ouverte pluridisciplinaire HAL, est destinée au dépôt et à la diffusion de documents scientifiques de niveau recherche, publiés ou non, émanant des établissements d'enseignement et de recherche français ou étrangers, des laboratoires publics ou privés. 


\title{
The French defence industry in the knowledge management era:
}

\section{A historical overview and evidence from empirical data}

\author{
Sarah Guillou †, Nathalie Lazaric $\ddagger$, Christian Longhi łand Sylvie Rochhia $\ddagger$
}

† OFCE, GREDEG, 250 rue Albert Einstein, Sophia Antipolis, 06560 Valbonne, France.

‡ UNSA-CNRS, GREDEG, 250 rue Albert Einstein, Sophia Antipolis, 06560 Valbonne, France.

\section{Corresponding author: Nathalie Lazaric (lazaric@gredeg.cnrs.fr)}

\begin{abstract}
:
In the defence industry the recent development of a 'market for technology', the creation of new European high-technology companies as well as transformations in government agencies have driven firms to reposition their technological and organizational skills. Our objective is to show that the transformations that have occurred in the past ten years have not only redefined skills and the organization of production, but also have given a more strategic place to knowledge management (KM) practices. We provide a contextual and historical overview based on qualitative interviews, in order to better understand the relation between $\mathrm{KM}$ and innovative behaviour in this industry. We build an original industrial and technological database comprising various samples that provides quantitative information concerning KM and innovative practices. The results of the statistical analysis reveal the specificity of firms in this industry. Taking account of the size of these firms and their technological intensity, we show that the behaviour of defence industry firms in terms of KM practices, differs from that of other firms. This is evident from their technological performance, and innovation and patenting intensity. This structural tendency is explained as an innovative behaviour in the French national innovation system rather than merely a 'trend'.
\end{abstract}

Keywords: Defence Industry, Knowledge Management practices, R\&D, Innovation, Technological Performance. 


\section{Introduction}

In 1997 the French defence industry underwent a major transformation following the government's decision to reduce budgets and manpower in this domain. This reduction in the funds dedicated to defence has generated a break from 'capitalism à la française' and a remarkable reconfiguration of government agencies and firms (Serfati 2001; Mustar and Laredo 2002; Guichard 2005). In the same year, the 'national champions' underwent a process of privatization and Europeanization of their organizations, and a redefinition of their knowledge base. The French defence industry is not unique in having experienced such a transformation; some years earlier, the British defence industry was subjected to similarly drastic changes with the emergence of more competitive markets (Avadikian and Cohendet 2005; Dowdall 2004; Molas-Gallart and Tang 2006).

These changes, which have resulted in the creation of new European high-technology companies, could have been used as an opportunity for creating new industrial architectures and for developing new capabilities (Jacobides et al. 2006). However the specific environment of the defence industry as well as the division of labour and technological skills that prevailed before these transformations, limited the scope of these opportunities (Acha and Brusoni 2008). Moreover, in an era of resource depletion, the reinforcement of organizational capabilities enabling firms to better identify technological know-how and its future development appear to be critical. Consequently, Knowledge Management (KM) practices have become an integral part of innovative strategies (Coombs and Hull 1998; Foray and Gault 2003; Kremp and Mairesse 2003; Guillou et al. 2005) to better explore the firm’s future development. 
Although, at first sight, KM practices might seem contradictory within the tradition of secrecy that has prevailed in the defence industry, our qualitative study reveals a different picture: government agencies and firms have a long tradition of formalizing and articulating their know-how in order to be able to justify their technological options and to guarantee the traceability of past projects (Majchrzak et al. 2004). Our interviews show that firms have had KM policies in place for some time, but that they have not been explicit or generalized and, consequently, have not been widely diffused. Thus, the development of KM practices was seen as providing a way of coping with the scarcity of resources and increasing the value of the knowledge base.

However, KM practices and their wide diffusion is a new tendency in the French national innovation system (NIS). As already mentioned, firms are facing these challenges within a new institutional context (Serfati 2005). In addition, the diffusion of electronics in both weapons systems and command and control networks has provoked a significant rupture with the diffusion of a new technological paradigm, and has created new links between civil and military products (Dowdall et al. 2004). In this perspective, KM programmes have evolved gradually, to become a strategic component of innovative policies and to play a critical role in managing knowledge. Moreover, as no organization on its own can manage all the knowledge that is necessary for the design and realization of systems and sub-systems, knowledge integration and knowledge coordination have become vital for firms in this industry (Grant 1996; Hobday et al. 2005; Acha and Brusoni 2008).

This paper is organized as follows. Section 1 outlines the theories and goals of KM and discusses the specificity of the French defence industry. We show the key role played by some government agencies in promoting $\mathrm{KM}$ practices and in repositioning know-how and skills within the NIS. Section 2 deals with methodological and statistical issues in the 
elaboration of an original French data sample to provide an accurate empirical picture of the impact of KM policies in firms, in relation to their innovative behaviour. The impact of KM practices on performance is also discussed. We conclude with some pointers to the originality of our research and proposals for topics for further research.

\section{Section $1 \mathrm{KM}$ practices in the defence industry: the state of the art in the French NIS}

KM practices in the defence industry ${ }^{\mathrm{i}}$ cannot be understood outside of their institutional and historical context, which has created strong path dependencies. Although both firms and government agencies have participated in the diffusion of $\mathrm{KM}$ practices, their goals and objectives remain quite distinct. We will explain this complementarity and show why firms in the defence industry use KM practices as a means of reinforcing their innovative positions. Based on a review of the literature we show the relation between KM practices and $R \& D$ policy. Using stylized facts based on our qualitative interviews we elaborate hypotheses related to KM practices and their emergence.

\subsection{KM: definition and goals in the defence industry}

Recently, much attention has been paid to policies related to KM to identify and preserve technological skills and to shed light on organizational capabilities. KM practices mostly involve R\&D, innovative policies (Coombs and Hull 1998) and the search for medium and long-term performance (Kremp and Mairesse 2003).

'Knowledge management (KM) covers any intentional and systematic process or practice of acquiring, capturing, sharing and using productive knowledge, wherever it resides, to enhance learning and performance in organisations. These investments in the creation of 
'organisational capability’ aim at supporting - through various tools and methods - the identification, documentation, memorization and circulation of the cognitive resources, learning capacities and competencies that individuals and communities generate and use in their professional contexts. Practices, like formal mentoring, monetary, or non monetary, reward for knowledge sharing and the allocation of resources to detect and capture external knowledge, are examples of knowledge management' (Foray and Gault 2003: 12).

KM policy is a way of preserving knowledge and of focusing attention on crucial know-how: tacit, codified or articulated (i.e. know-how embedded in human minds, knowledge articulated in the form of patents, knowledge codified in various ICT tools). The degree to which the articulation and codification are adopted by organizations can differ radically, depending on the costs and benefits for the particular firm, its strategic vision and the importance attributed to the development of capabilities (Teece 1998; Zollo and Winter 2002; Lazaric et al. 2003; Denrell et al. 2004).

In the defence industry, a related issue refers to the traditional decision between spin-off $v s$. spin-in, as in the digital age, R\&D and technology are no longer dedicated to but rather are adapted for military uses (Stowsky 2004). In this context, the duality of knowledge may generate transformation of the know-how for various uses (civilian and military), and may create opportunities for its recombination, particularly in the case of complex products and systems (CoPS). On the other hand, firms and government agencies need to develop new organizational and technological capabilities 'to define and combine all the necessary inputs for a system and agree on path of future systems developments' (Hobday et al. 2005: 1110). These 'integration capabilities' are necessary for various reasons. First, because the distribution of knowledge is not always concomitant with the division of labour and in some 
cases 'firms know more than they make' (Brusoni et al. 2001). Second, in order to achieve really dynamic coordination, knowledge management must be consistent with the objective of innovation and of development of a broad knowledge base capable of providing the input necessary for the design and development of technologies within the firm, or in collaboration with external partners. New types of relationships among various organizations are required therefore, for the purposes of knowledge development and preservation, even though this objective might seem not to equate with KM related objectives.

To be more explicit, according to Grundstein (2001), we can draw a distinction between two major objectives in KM. Firstly, KM can be oriented to a long-term purpose and to the accumulation of large depositories of knowledge (in the nuclear and space sectors, this need for exhaustive data can be extremely critical in order to avoid technological disasters). Secondly, knowledge can be preserved to fulfil an 'innovative objective'. Here, there may be a short-term perspective and the knowledge acquired through past products and projects can be used for the development of new ones (Argote 1999; Majchrzak et al. 2004). This is certainly the most frequent KM policy goal.

Grundstein`s distinction of the objectives of KM policies is relevant in the French context, where government agencies have clearly evolved over a long time frame in terms of knowledge preservation policies, whether oriented to the past, the future or both (Grundstein 2001). The problems confronting these government agencies include the need to provide collective pre-competitive knowledge, and to ensure its longevity of knowledge in the context of the French NIS (Papon 1998; Mustar and Laredo 2002). For government agencies, the preservation of know-how related to military uses is a sensitive issue. This explains why the 
French Atomic Energy Commission (CEA) has implemented significant initiatives paving the way to experimentation in this field.

For market-oriented firms, KM practices may vary because questions related to the decomposability of knowledge and its integration have become fundamental issues (Prencipe 1997; Davies and Brady 2000; Hobday 2000; Hobday et al. 2005). Private firms explore some available opportunities to reinforce their competitive advantage; and pay particular attention to technological and organizational capabilities in order to gain the distinctive and distributed abilities required for design and manufacturing (Acha and Cusmano 2005; Acha and Brusoni 2008). Below, we describe these dimensions in more detail.

\section{2. Institutional change and the historical context related to the implementation of a KM policy in France}

Implementation of a KM policy in the French defence industry was accelerated by the announcement in January 1995, by the then French President, Jacques Chirac, that nuclear tests were to be discontinued. ${ }^{\mathrm{ii}}$ This triggered the creation of a true KM policy no longer involving merely the accumulation of data concerning nuclear tests, but focusing on preservation of the knowledge acquired in the field. The French Atomic Energy Commission (CEA) was directly affected by this announcement, and other government agencies, such as the French Armament Procurement Agency (DGA) and the French Aeronautics and Space Research Centre (ONERA), were faced with the need to justify their skills, and were inspired by this experience to implement their own KM tools.

After the interruption to nuclear testing, a Knowledge Exploitation Centre (CEC) was created within the French Atomic Energy Commission to archive existing knowledge and to distribute it 
and accumulate new knowledge that could be used for the later development of weapons. The main mission of this department was to identify critical know-how acquired in the past, in order to build the knowledge-based system necessary to obtain the latest information relevant to nuclear weaponry. ${ }^{\mathrm{iii}}$ In addition, it was responsible for accumulating knowledge in the field because a wave of retirements resulting in a considerable reduction in manpower was threatening loss of tacit knowledge on the design, maintenance, and dismantling of nuclear weapons.

Thus, the aging labour force, ${ }^{\text {iv }}$ the length of time required to develop new nuclear weapons and the interruption to nuclear testing led to the implementation of a $\mathrm{KM}$ policy. ${ }^{\mathrm{v}}$ It was important for strategic reasons (not necessarily clear at the time) that the articulated and tacit knowledge produced over the years should be preserved. An extensive KM policy known as the 'Ultime Rafale' programme was then introduced. These events also marked the end of a policy related to the mere accumulation of facts and data, and its replacement by a programme whose objective was to model and codify the knowledge acquired in nuclear testing, to improve understanding and reduce failure rates ${ }^{\mathrm{vi}}$.

At the heart of this KM policy is a truly new methodology, known as the Method for Knowledge Systems Management (MKSM), ${ }^{\text {vii }}$ which has been transferred to all the relevant government agencies, including DGA - the French Armament Procurement Agency, and to firms, such as the European Aeronautic Defence and Space Co. (EADS).

The changes that have occurred in the last few years have driven government agencies to rationalize their activities. ${ }^{\text {vii }}$ DGA's investments in upstream research have significantly decreased (Guichard 2005) and have been redirected toward the manufacturing stage. ${ }^{\text {ix }}$ The loss of technological skills induced by this change has been partly compensated for by the 
development of collaborative networks and transfers of knowledge among firms. Moreover, the more frequent use of civil technologies, the increase in $R \& D$ subcontracting, and the more careful selection of research themes by government agencies have had significant consequences for KM. For instance, in several technological fields, DGA has switched from its traditional role of Lead System Integrator (LSI) to a 'market oriented' position, which raises the question of which technological skills should be preserved and continuously developed internally.

In 1997, a new purchasing policy was implemented, inspired by the 'smart procurement' principle introduced in the United Kingdom (MoD 2001), aimed at reducing costs and diversifying procurement. Its consequences were not limited to the budget; DGA was required to restructure its competencies. Most had been related to upstream research and the overall architecture of systems; gradually, these competencies have moved towards more applied research in order to support technological development (foresight exercise) and maintain technological and scientific competencies, so as to better understand the new materials specifications. This has meant that DGA has inexorably progressed towards more downstream activities in order to better identify military needs (Guichard 2005).

To cope with this strategic repositioning, DGA has transferred some of its traditional technological and organizational skills, ${ }^{\mathrm{x}}$ which in its turn has promoted changes in French companies. In 1997, the privatization of Thomson CSF highlighted the duality of knowledge. There has been an evolution towards management of dual technologies on the one hand, and creating multi-technology companies capable of developing the technological alliances necessary for their own development on the other (e.g. Thales, created in 2000, focuses essentially on military applications and Thomson Multimedia concentrates on civil 
technologies). The change has not been only technological. DGA first transferred some of its organizational skills - notably its LSI capability - to firms. Thales acquired a part of this expertise in the field of naval shipbuilding through its agreement with the Directorate for Naval Construction (DCN). DGA gradually refocused on the managerial skills required to understand future technological developments.

This involved DGA making an inventory of its experts to ensure that no critical competencies were overlooked (e.g. in the field of cryptology), and to maintain technological operating competencies. Test centres play a critical role in preserving minimal levels of understanding and housing quantities of tacit knowledge. Thus, the adoption in 2004 of a KM policy by the DGA- partly inspired by the CEA's experience in making an inventory of its skills- is an illustration of the type of transformation that has occurred within the NIS. As a result, DGA has had to identify critical skills and maintain them, making use of external networks. In other words, the objective has been to outsource and to monitor these networks on the basis that certain skills are no longer owned by individual organizations, but evolve through various kinds of partnerships.

\subsection{The impact of these transformations on firms and the implementation of $\mathrm{KM}$ policies}

The question of what kind of knowledge should be preserved is not reserved to government agencies. Firms, such as EADS and Thales, which develop new organizational capabilities, face similar challenges in relation to their core capabilities. These firms have evolved from ordinary assemblers to Lead Systems Integrators (LSI), which has required the absorption of new knowledge and capabilities. In this context, KM policy can be explained by several factors. 
1) The repositioning of high-technology companies in the global value chain is critical in the defence industry (Dowdall 2004; Acha and Brusoni 2008; Hobday et al. 2005). EADS, for example, has had to abandon its previous division of labour (between Aérospatiale, VFW, $\mathrm{MBB}$ and $\mathrm{BAE}$ ) in order to manage the coordination of various system interfaces and be able to fully assume its new role of 'knowledge integrator'. This has led to twin processes of vertical integration -in the area of materials and equipment maintenance - and a process of disintegration in certain technological fields such as avionics and composites and plastics. To this end, in 2001 EADS created a Centre of Competences (COC) to facilitate coordination with suppliers and technological partners and to maintain some of its technological skills.

2) The distribution of core capabilities between various geographical sites requires the creation of a common culture to harmonize European competencies and develop a real European expertise. The implementation of KM policies has allowed the 'communities of practices' that existed before the high-technology companies were created, to be acknowledged, and communication between organizations that previously competed against one another to be promoted.

3) Finally, the necessity to take better advantage of the duality of knowledge generated by each entity in the military and civil technological systems, and the careful management of potential spin-in within each modular element (e.g., electronics components developed by Thales can be used for military purposes after some modification). This is an important issue as only a portion of the turnover of the very high-tech companies is generated by the sale of military products (in 2005, 22\% for EADS, 60\% for Thales and 52\% for Dassault). 
For all the reasons presented above, there have been many opportunities for firms to implement KM practices linked to a technological policy requiring a better understanding of firms' knowledge bases in order to compete in the 'markets for technology'. However, as we will show, implementation of $\mathrm{KM}$ practices has various objectives and may be oriented towards the easy re-use of current knowledge. To illustrate this, we provide two examples from EADS and Thales.

In June 2001, Thales launched a KM project. Its principal aim was the creation of a shared language among 13 communities of practices, and the building of coherent and generic subsystems that could be used for various technological projects (a kind of modular strategy implying minimal codification among the various parts of the sub-systems). The software community played a critical role in building a technical platform to facilitate technological modularity, and creating a common technical language. Attempts were made to expand this platform to other technological fields, particularly expertise and project management. In Thales, the KM policy is oriented in part towards knowledge re-use in projects, in order to take advantage of the software modularity, and in part because of the necessity to preserve crucial know how through patents ${ }^{\mathrm{xi}}$ and knowledge holders. ${ }^{\mathrm{xii}}$ This policy is driven by the need to achieve a degree of knowledge integration and to improve the company's knowledge base and innovative activity.

In EADS, there is a permanent interplay between 'communities of practice' and networks of researchers. ${ }^{\text {xii }}$ EADS was founded in 2000 as the result of a merger between Aerospatiale, DASA and CASA, and one of its main challenges has been to link these various entities. To this end, EADS-France split its KM activity across two centres: a research centre in Suresnes and a production centre in Toulouse, where Airbus aircraft are manufactured. EADSGermany has adopted a similar approach in the hope of promoting communication between 
the different organizational entities. EADS’ KM policy aims are to provide various tools for the production of ICT kits to satisfy operational needs and more generally to enable the re-use of pre-existing ICT systems in a modular scheme, and to develop a common technical language within the firm in order to take full advantage of this modularity. A KM tool known as 'Ingenium' has been created by CEA-DAM and adapted for non-nuclear application by EADS. Other tools have been elaborated by EADS engineers at the Research Centre in Suresnes. The ANITA platform is one example of a tool created within the company, that has facilitated coordination among different networks as well as development of a distributed memory adapted to various needs. ${ }^{\text {xiv }}$

EADS has also implemented a knowledge articulation policy - within Airbus- through the compilation and production of a knowledge handbook. As such an approach, which was inspired by MKSM, is costly, there is a trade off between costs and benefits, which has caused the firm to favour a short-term policy of efficiency and innovation over long-term knowledge preservation.

In sum, in the French NIS, CEA has played a crucial role through the diffusion of KM tools created by researchers and adapted to the specific needs of ONERA and EADS. KM activities are viewed very differently by government agencies and firms. Government agencies develop KM with the aim of knowledge preservation, while firms generally want to implement KM practices to improve their performance in competitive markets. These seemingly contradictory objectives, work together to facilitate the accumulation of knowledge in the NIS, and although the objectives of firms and government agencies in implementing $\mathrm{KM}$ policies are very different, their motivations are similar: scarcity of funds, aging manpower, improved performance and justification for current choices related to technologies and competencies. 
This explains why KM has many different purposes and can be implemented very differently. Knowledge handbooks illustrate these differences, which could be used in firms and government agencies alike, but are generally only diffused in the latter.

\subsection{Some hypotheses related to KM practices}

Based on the stylized facts we gathered during our qualitative interviews (see Appendix 2) and our review of the literature, we can propose some hypotheses concerning the measurement and testing of KM practices in the defence industry:

H1 KM is specific and, to a certain extent, different in the defence industry compared to other traditional industries

This hypothesis is based on observation of the defence industry characterized by CoPS, as well as standard products and military projects (Hobday et al. 2000). The technological specificity of CoPS generates distinctive knowledge that has to be preserved and memorized in a specific way (which differs from the methods used in the agro food or automobile industries). Military markets are complex with longer or shorter production cycles, depending on the nature of the project implemented. Articulation and codification of knowledge via KM are essentially related to technological issues (knowledge modularity, identification of experts and inventors), but also to some organizational dimensions (notably knowledge from specific projects, which is needed for reuse in others).

H2 There is a link between innovative activities and KM activity

Firms in the defence industry have clear $R \& D$ policies and put great emphasis on technological knowledge accumulation in orienting their projects and products. This leads 
them to combine existing knowledge from current technological trajectories and future markets. Most firms are high technology companies with a large and coherent knowledge base that serves as a foundation for future innovative activities (Nesta and Saviotti 2006). Because knowledge is distributed within the organization and difficult to manage, knowledge systems integration has become a core technological and organizational capability. Knowledge integration (Grant 1996) underlines the fact that knowledge accumulation is a path-dependant process more likely to occur in related technological areas than in unrelated fields (Breschi et al. 2003).

\section{H3. KM policies are not limited to firms}

Firms in the defence industry have increasing recourse to the 'market for technology' to acquire new technological skills (Acha and Brusoni 2008). The integration of external knowledge requires a minimum level of ‘absorptive capacity’ (Cohen and Levinthal 1990). The relation between KM and innovative strategy is increasingly critical in this context, for identifying the core competencies that must be preserved internally and those that should be developed in partnership with other companies (Revilla et al. 2005). Multi-technology firms need to have excess knowledge in order to cope with unpredictable developments in new technological fields. They belong to networks in order to benefit from opportunities that may emerge from specialized suppliers. This is the reason why multi-technology 'firms know more than they can make’ (Brusoni et al. 2001).

H4 KM policy is oriented to improving economic and technological performance There may be a link between the firm's knowledge base (notably its coherence and its scope) and its performance (Nesta and Saviotti 2006). According to Kremp and Mairesse (2003) knowledge management practices when combined can improve the firm's productivity. These 
authors studied responses relating to four practices, from the French Community Innovation Survey (CIS3). Their results tend to confirm that there is a significant relation between a firm's innovative performance and its productivity. We expect that this might apply to the defence industry, which has a large presence of large high-tech companies. But although HRM (human resource management) policy can have an impact on employees' skills, the link between practices -particularly training- and firms’ performance measurement and KM policy requires further exploration (Delaney and Huselid 1996).

Section 2: Construction of indicators for KM practices and innovative behaviour in the defence industry

We present our statistical results and check their correlation with the above hypotheses. First, we explain how, using various statistical sources, we obtained different groups of firms designed to fulfil our empirical goals. Following this statistical and methodological overview, we present our results for KM policies. In particular, we show the relation between KM and innovation, and we try to demonstrate why the specificity of the defence industry is far from trivial.

\subsection{Identification of the French technological defence base: data and methodology}

Despite its absolutely basic importance, $\mathrm{KM}$ in the defence industry has not been the object of in-depth empirical analysis. An important reason for this is the absence of dedicated statistics databases with appropriate indicators (Molas-Gallart 1999; Hartley 2006). In order to respond to this problem, we match new data on KM included in CIS3 - a result of a pilot project 
initiated by the OECD with the introduction of complementary survey related to KM practices (see Foray and Gault 2003)- with data from the French Defence Ministry. Data from the French CIS3, which also provides important information on the strategies implemented by innovative firms, represents the fundamental statistical information used here.

As outlined at the beginning of this article, firms in this field do not restrict their industrial and technological bases to defence activities; in other words they do not strictly and only depend on the State’s budgets and public military markets (Versailles 2003; Dowdall 2004). Thus, firms in defence industry were not selected according to the characteristics of their products or to the sectors to which they belong. As underlined by Dunne (1995: 404), 'definition of the defence industrial base needs to be chosen to suit the empirical analysis being undertaken and the practical problems of data availability’.

Firms' dependence on the needs of the Defence Ministry, and reciprocally, the Defence Ministry's dependence on the production of firms, are relevant criteria. As a consequence, the firms in the defence industry- considered here - are those that are direct suppliers to the Defence Ministry. Despite their evident relevance, we do not consider indirect suppliers, which are dependent on the demands of the direct suppliers, because of lack of information. The source of information allowing the identification of direct suppliers is the French database SANDIE. ${ }^{\mathrm{xv}}$ Finally, because our interest lies in the innovation process and KM, the analysis is restricted to firms that implement private $R \& D$. Thus, these two sources of information ( CIS3 and SANDIE) are augmented by information from the French R\&D survey, ${ }^{\text {xvi }}$ which consists of data on all French firms conducting R\&D. It provides information on number of researchers, $R \& D$ spending, patents, etc., and information on the different sources of finance (private, public) for firms' in house R\&D. In particular, it enables us to identify firms whose R\&D is partly financed by the Defence Ministry. 
Thus, the information provided by these different surveys has enabled us to build three main datasets:

- B0: The firms implementing R\&D. This includes all the firms responding to the R\&D survey, that is, potentially all French firms that have undertaken private R\&D in France, regardless of the sector;

- B1: Defence suppliers. This set includes, among those that implement R\&D (B0), those firms that are in the defence industry, that is, suppliers surveyed by SANDIE;

-B2: Defence suppliers whose R\&D is partly financed by the Defence Ministry, that is, suppliers surveyed by SANDIE that conduct private R\&D, which is firms included in the R\&D survey, whose R\&D is partly financed by the French Defence Ministry.

The principle governing the elaboration of our samples B0, B1, B2 is a principle of inclusion. All firms considered in the research belong to B0. The firms in B1 have one link with the defence industry: they are suppliers. The firms in B2 have two links with the defence industry: they are suppliers, and their R\&D expenditure is partly financed by the Defence Ministry. The B2 firms are clearly more dependent on the institutional context prevailing in this industry.

In addition to these three samples of firms, it is useful to consider exclusive sets to link specific characteristics to specific behaviour. Thus, we define also:

- $\quad$ B0-B1 (B0 minus B1): Firms that implement R\&D, but that are not defence suppliers;

- $\quad$ B1-B2 (B1 minus B2): Firms that are defence suppliers, but whose R\&D spending is not financed by the Defence Ministry. 
Before looking at KM practices gleaned from the responses to CIS3, we provide some general information on these different sample sets, to identify the variables to be controlled.

Table 1 indicates the average values of the structural variables in each dataset for the period 1998-2000. The size of the different samples shows that Defence Ministry contributes to financing R\&D in only a small number of companies.

\section{INSERT TABLE 1 HERE}

The firm size increases in line with the dependence on the Defence Ministry. In addition, small firms are over-represented in B0 compared to the other two sets (i.e. the closer the relationship with the Defence Ministry, the larger are the firms). Indeed the class [100, 500[ is the most important class in the B0 and B1 sets, while the class [more than 500[ is dominant in B2. R\&D expenses are also quite dissimilar among these sets. Traditionally, French statistics distinguish internal R\&D spending (DIRD) from external R\&D spending (DERD), their sum being the total R\&D expenses of the firms. Table 2 summarizes these data.

\section{INSERT TABLE 2 HERE}

The differences between B0 and B2 are very important - approximately 1 to 10- for DIRD as well as DERD. Clearly, firms in the B2 sample represent the core of the NIS, and account for the largest part of private research. They also receive most of the public subsidies, the share of public financing amounting to $9 \%$ and $26 \%$ for B0 and B2 respectively, of which in $\mathrm{B} 2$, 
20.5\% comes from the Defence Ministry. Research intensity, measured by the ratio Total R\&D expenditure on Turnover, increases from 3.8\% to $10.7 \%$ for $\mathrm{B} 0$ and $\mathrm{B} 2$. These results show that there is a huge gap in terms of firm behaviour and involvement in R\&D. These differences in structural variables will need to be controlled for in analysing the impacts of KM policies. Potential differences in KM practices in the three sets (B0, B1 and B2) could be due to the size effects within each set. Consequently, we conducted the following descriptive statistical analysis to shed light on the context and emergence of KM practices, to have a better understanding of the specific behaviour of firms in the defence industry.

\subsection{KM practices in the defence industry}

CIS3 gives information about the KM practices of innovative firms. Four KM policies are investigated:

- KM1: a written KM policy;

- KM2: a knowledge sharing culture;

- KM3: an incentive policy to retain employees;

- KM4: alliances for knowledge acquisition.

As proposed by Kremp and Mairesse (2002), an indicator of the level of KM is obtained by summing the number of different KM practices implemented by firms. We call this indicator KMI, and it takes the value 0 to 4 according to whether the firm uses none, one, two, three or four of these KM practices. This indicator provides a simple overall measure of KM intensity (KMI) in the firm.

Table 3 indicates the percentage of firms exploiting each KM practice, in each sample, and the percentage of firms in each sample that use $0,1,2,3$ or 4 policies. 


\section{INSERT TABLE 3 HERE}

Among B2 firms, 38\% implement a written KM policy compared to 31\% of B0 firms. This difference becomes more significant when so-called 'alliances for knowledge acquisition' policy (KM4) are considered: 72\% of B2 firms form alliances for the purpose of knowledge acquisition whereas only $42 \%$ of B0’s firms do so.

Thus, except for the written KM policy, the relationship with defence is associated with stronger KM practices. The more that firms are part of the industrial dynamic of the defence industry, the more they are involved in KM policies. Obviously, R\&D is a major determinant. In order to provide a more overall picture, calculation of the average of the KMI indicator for each sample of firms confirms that KM practices are more widespread in the defence industry, given that there are twice as many KMI for B2 (2.4) as B0 (1.3). With regard to the KMI indicator, $57 \%$ of $\mathrm{B} 2$ firms implement more than $2 \mathrm{KM}$ policies while the figures are $37 \%$ for B1 firms and 30\% for B0 firms. The results for B0-B1 and B1-B2 are consistent with the results obtained for B0 and B1. These results should be all interpreted taking account of firm size and technological intensity. KM practices are strongly correlated to size and technological intensity, as shown by Kremp and Mairesse (2003). The complementary questionnaire within CIS3 reveals that among firms that responded to questions on KM practices, $10 \%$ of those with 20 to 49 employees have a written KM policy compared to $50 \%$ of firms with more than 2,000 employees.

As the representation of large and high technological intensity firms is bigger in the defence industry, the more widespread KM practices in B2 could be the result of a defence relationship, or an effect of the bigger size of firms, or a by-product of their higher 
technological intensity. Chart 1 shows the KMI average for an increasing range of firm size, measured by its turnover in 2000. As expected, KM practice is correlated with firm size in each sample, but it also seems that for firms of the same size, the defence characteristic seems to be an autonomous determinant of KM practise. Whatever the size of the firm, the KMI average is bigger for firms that belong to the defence industry.

\section{INSERT CHART 1 HERE}

Thus, large firms are more likely to implement KM practices. But what also is interesting is that, among firms of the same size, those in the defence industry, on average, implement more KM policies.

Level of technological intensity is also often correlated with KM practices. Technological intensity is traditionally evaluated as the ratio of the R\&D spending on turnover. We use four classes for this ratio, given by the quartiles of the whole sample.

Descriptive statistical analysis shows that firms in the defence industry on average have a higher technological intensity than other firms that conduct R\&D. Previous figures show that technological intensity (investment in R\&D related to average turnover for 1998-2000) of B2 firms is $19 \%, 6 \%$ for $\mathrm{B} 1$ and $7 \%$ for $\mathrm{B} 0$.

Studying the relationship between the level of KMI (from 0 to 4) and technological intensity leads to the following conclusions. A high level of KM (superior or equal to 3) is more frequent for high technological intensity firms. A low level of KM (0 and 1) is more frequent for low technological intensity firms. Among high technological intensity firms, 55\% of firms implement three or four KM practices. But among low technological intensity firms, $17 \%$ implement more than three KM practices. 
In order to take account of the specificity of firms in the defence industry, we calculated the average KMI for each level of technological intensity, for each sample. Chart 2 presents the results. B2 firms show the highest average KMI, whatever the technological intensity. This means that the defence relationship again seems to be a determining factor in explaining KM practice not necessarily linked to the high level of technological intensity of firms belonging to this industry.

\section{INSERT CHART 2 HERE}

From these statistical observations, we can say that hypothesis H1 is supported. Indeed, these results tend to confirm our qualitative interviews, notably in relation to the importance of preserving knowledge in this industry. Most B2 firms are providers of high innovative equipments. Moreover, the labour market is smaller and labour force turnover is lower, which makes it easier to preserve the knowledge of experts and engineers. B2 firms are similar to many other innovating firms: they belong to many different networks in order to benefit from the duality of their knowledge and to acquire complementary assets (Jacobides et al. 2006). Thus, KM practices were being used long before KM became 'fashionable’; they represent the traditional way of 'doing things'. This explains the structural tendency observed in the B2 sample. We next address hypotheses H2 and H3.

\subsection{KM practices and technological performance}

Competence and knowledge are major determinants of innovation in firms. They have a bigger impact on technological productivity when $\mathrm{KM}$ practices are more widely implemented. In other words, there should be a correlation between higher levels of KM and 
the levels of knowledge and competences, that is, levels of $R \& D$ investment. We would expect that firms with high levels of $\mathrm{KM}$ would demonstrate higher technological performance, that is, higher levels of innovation. CIS3 provides two indicators of technological performance: innovation intensity and patent intensity.

\subsubsection{Innovation intensity and KM practices}

Innovation intensity is defined as the percentage of turnover related to the sale of new or radically modified products. In 2000, average innovation intensity was $7 \%$ for B0 firms (6\% for B0-B1), $9 \%$ for B1 firms (9\% for B1-B2) and 13\% for B2 firms. There is a clear ranking between B0 and B2: the stronger the firms' links with defence, the higher is their average innovation intensity. To see how KM practices affect innovation intensity, we compute the average innovation intensity conditional on the KM indicator for each sample.

Chart 3 shows how KM practices interact with innovation intensity for each sample of firms.

As can be seen from Chart 3, the average innovation intensity of B0-B1 firms, in the absence of $\mathrm{KM}$ is $4 \%$, but this rises to $10 \%$ if four $\mathrm{KM}$ practices are implemented. As expected, the corresponding figures for B1-B2 and B2 are higher. This means that B2 firms have a higher innovation intensity on average than B1-B2 firms, which have a higher innovation intensity than B0-B1 firms.

\section{INSERT CHART 3 HERE}

Chart 3 shows also innovation intensity increasing with a higher level of KM regardless of the sample. This suggests that KM practices are positively correlated with innovation intensity. But this positive relationship appears not to be linear for B2 firms. These firms are characterized by high technological intensity when the KMI equals 1 ; when KMI equals 2, 
innovation intensity is lower than in the other samples. It should be remembered that the larger the sample, the more robust it will be and the less will be the fluctuations caused by firms with specific behaviours. Chart 4 indicates the KMI average for different quartiles of innovation intensity in sub-sample B2. The higher the innovation intensity of B2 firms, the higher is the average KMI.

\section{INSERT CHART 4 HERE}

These results, to some extent, are consistent with our qualitative interviews, which indicate that firms in this industry are also involved in the race for innovation. For this reason, they dedicate an important part of their activity to the 'market for technology' in order to renew their knowledge base. As we saw earlier, the repositioning of these companies in the global value chain is a critical issue (Dowdall 2004; Acha and Brusoni 2008). In order to take greater advantage of the externalities in some technological alliances and to generate co-specialized assets, these companies place much emphasis on the evolution of their internal capabilities in the space industry these assets are represented by the development of a joint technical platform by EADS and composite producers to study certain specific characteristics of these materials before their implementation in Airbus. Consequently, these firms devote great efforts to knowledge articulation and knowledge codification, illustrated by the importance given to KM practices. KM practices, in our view, are an indicator of this tendency and are the visible part of the iceberg of innovative behaviour in B2 firms.

\subsubsection{Patent intensity and KM practices}

Patent intensity is the percentage of turnover that is protected by patents. We calculated average patent intensity for 2000 based on the level of KM in each sample. Chart 5 shows 
first, that the relationship between average level of patent intensity and level of $\mathrm{KM}$ is positive (from 0 to 4). Patent intensity on average is always highest among firms with the highest levels of KM. Second, it illustrates that generally firms in the defence industry have higher patenting intensity than other companies, with the exception of firms whose level of $\mathrm{KM}$ is equal to 2 .

\section{INSERT CHART 5 HERE}

In other words, overall we find higher levels of patenting intensity in the B2 sample, except when $\mathrm{KMI}=2$. Chart 5 does not discriminate among patent intensities for firms in the B0-B1 and the B2-B1 sets, for all levels of KMI, that is, for all French firms implementing in house R\&D without funding from the Defence Ministry with the exception again of B2 firms.

This result might seem surprising, because firms in the defence industry might be expected to have a low propensity to patent. Our results are due to the fact that B2 firms appear to be diversified and multi-technology. Also, in our view, their high levels of patenting intensity reveal a strategy of fully exploiting their knowledge base both within and outside the defence industry, especially in new fields (see Thales for an example in electronics). Moreover, as Griliches (1990) shows, patents are not only a production output, they are also a good proxy for the knowledge base. Consequently, in the French context, the performance observed here should be viewed more as an output of these firms' technological capabilities, than as a characteristic of the defence industry. 


\section{Conclusion}

The analysis aimed to investigate the development of KM practices in the French defence industry. We presented the historical context in which $\mathrm{KM}$ practices have emerged and developed indicators for identifying and measuring innovative behaviours.

The information gleaned from qualitative interviews was essential for understanding what happened after the 1997 reform of DGA and, in particular, why so much emphasis was placed on minimizing costs and preserving knowledge. As we have seen, various changes in several government agencies played major roles in defining new capabilities in this industry. Thus, the development of KM practices provided a means of coping with the scarcity of resources and increasing the value of the firm's knowledge base.

We developed various samples of firms, starting with all French firms conducting R\&D, and distinguishing those supplying the Defence Ministry, and among these, those whose $R \& D$ was partly financed by the Defence Ministry. The paper shows that for the same technological intensity, characteristics related to defence emerge as strong, specific determinants of KM practices. Innovation intensity and patent intensity are stronger in this industry at all levels of $\mathrm{KM}$ and firms in the B2 set seem to perform better than others. Thus, our analysis has shown that $\mathrm{KM}$ activities are related to innovation activities and technological performance, but that, in addition, relationship with defence clearly differentiates firms. The group of firms whose R\&D activities are financed by the Defence Ministry is distinctive, KM oriented and more successful. Thus, the selection process undertaken by the Defence Ministry - to a certain extent- is quite effective. This does not mean that this is necessarily a causality link, but that, at minimum, the higher performing firms are selected.

More generally B2 firms, which appear to be at the core of the French NIS, are those that receive the most public subsidies. This creates a self-reinforcing process, which could perhaps 
explain the technological performance observed. As Ruttan (2006) emphasizes, a large part of the success of the defence industry is driven by public funding and by the active commitment of governments to sustain risky technological trajectories, which private firms are reluctant to do. Further research would be useful to examine this critical issue more thoroughly; it is inherent in all European countries that actively finance defence-related R\&D and are keen to extend and preserve their technological expertise in this highly strategic sector.

Finally, future research is needed to construct economic indicators that would enable us first, to extend our observations by providing a more precise picture of the French defence industry, and second, to develop supplementary statistical data about the industry, which at present is rather scarce. 


\section{References}

Acha V., Cusmano L., 2005, Governance and co-ordination of distributed innovation processes: patterns of R\&D co-operation in the upstream petroleum industry, Economics of Innovation and New Technology, Taylor and Francis Journals, 14 (1-2), 1-21.

Acha, V., Brusoni S., 2008, The changing Governance of Knowledge in Avionics, Economics of Innovation and New Technology, 17, (102), 43-57.

Agostino A., Guitton C. (Céreq), 2007, Tendances d'évolution de l'emploi et des qualifications dans la métallurgie, Bref, $n^{\circ} 239,1-4$.

Argote L., 1999, Organizational Learning: Creating, Retaining, and Transferring Knowledge. In, Organizational Memory. Kluwer Academic Publishers, pp. 67-97.

Avadikian A., Cohendet P., 2005, L’Émergence d'une économie de la Défense fondée sur la connaissance: quelques leçons tirées des réformes au Royaume-Uni (The Emergence of a knowledge based economy in defence industry: some lessons from the British reform), Revue d'Economie Industrielle, $4^{\text {ème }}$ trimestre, (112), 65-82.

Breschi S., Lissoni F., Malerba F., 2003, Knowledge Relatedness in Firm Technological Diversification, Research Policy, 32 (1), 69-87.

Brusoni S., Prencipe A., Pavitt K., 2001, Knowledge specialization and the boundaries of the firm: why do firms know more than they make? Administrative Science Quarterly, 46, 597-621.

Cohen W., Levinthal D., 1990, Absorptive Capacity: A new perspective on learning and Innovation, Administrative Science Quarterly, 35, 128-152.

Coombs R., Hull R., 1998, Knowledge management practices and path dependency in innovation, Research Policy, 27 (3), 237-253.

Davies A., Brady T., 2000, Organisational capabilities and learning in complex product systems: towards repeatable solutions, Research Policy, 29 (7-8), 931-953.

Delaney J.T., Huselid M.A., 1996, The impact of Human resource management practices on perceptions of organizational performance, Academy of Management Journal, 39, (4), 949-969.

Denrell J. Arvidsson N. Zander U., 2004, Managing knowledge in the dark: an empirical study of the reliability of capability evaluations, Management Science, 50, (11), 1491-1503.

Dowdall P., 2004, Chains, Networks and Shifting paradigms: The UK defence Industry Supply System, Defence and Peace Economics, 15 (6), 535-550.

Dowdall P., Braddon D., and Hartley K., 2004, The UK Defence Electronics Industry: Adjusting to Change, Defence and Peace Economics, 15(6), 565-586.

Dunne, J. P., 1995, The defence industrial base. Handbook of Defence Economics. K. H. T. Sandler. Amsterdam, Elsevier Science. 1, pp. 399-429.

Foray D., Gault F., 2003, Measurement of Knowledge Management Practices. In OECD report, Measuring knowledge Management in the Business Sector: First steps, OECD, pp.11-28.

Grant R., 1996, Prospering in Dynamically Competitive Environments: Organizational Capability as Knowledge Integration, Organization Science, 7 (4), 375-387. 
Griliches Z., 1990, Patent statistics as economic indicators: a survey, Journal of Economic Literature, (VIII), 1661-1707.

Grundstein M., 2001, Management des connaissances, modèles d'entreprises et applications (Management of knowledge, cases studies and applications), in Zacklad and Grundstein M. (eds) Hermes Sciences, Paris.

Guichard R., 2005, Suggested repositioning of defence R\&D within the French system of innovation. Technovation, 25 (3), 195- 201.

Guillou S., Lazaric N., Longhi C., Ngo Mai S., Rochhia S, 2005, Innovation, diffusion des connaissances et croissance : le cas des entreprises liées à la défense, OED report DAF/OED/2001/12, Report coordinated and directed by Lazaric N. (Innovation, diffusion of knowledge and growth: the case of firms related to defence industry) .

Gusterson H., 1992, Testing times: A nuclear weapons laboratory at the end of the Cold War, Thesis (Ph.D.) Research Org, Stanford Univ., CA (United States)

Hartley K., 2006, Defence R\&D: Data Issues, Defence and Peace Economics, 17 (3), 1-10.

Hartley K., Sandler T. (eds), 2001, The Economics of Defence, Elgar.

Hobday M., 2000, The project-based organization: an ideal form for managing complex products and systems?, Research Policy, 29 (7-8), 871-893.

Hobday M., Rush H., Tidd J., 2000, Innovation in Complex Products and Systems, Research Policy, 29 (7-8), 793-804.

Hobday M., Davies A, Prencipe A, 2005, Systems integration: a core capability of the modern corporation, Industrial and Corporate Change, 14 (6), 1109-1143.

Jacobides M.G, Knudsen T., Augier M., 2006, Benefiting from Innovation: Value Creation, Value Appropriation and the Role of Industry Architectures, Research Policy, 35, 1200-1221.

Kremp E., Mairesse J., 2002, La gestion des connaissances dans l'industrie, un atout pour l'innovation. Le 4 Pages des statistiques industrielles. Paris.

Kremp E., Mairesse J., 2003, Knowledge management, innovation and productivity: a firm level exploration based on French Manufacturing CIS3 Data, Measuring knowledge Management in the business sector, OECD, pp 143-168.

Lazaric N., Mangolte P.A., Massué M.L. , 2003, Articulation and codification of collective Know how in the steel industry: some evidence in the French blast furnace, Research Policy, 32, 1829-1847.

Lazaric N., Ngo Mai S., Rochhia S., 2004, Which kind of knowledge should be memorised in the defence-related industry or the trade off between collective and private knowledge: evidence from case studies, 10th International Schumpeter Society Conference, June, Milan.

Mac Kenzie D., Spinardi G., 1995, Tacit knowledge, weapons design and the uninvention of nuclear weapons, American Journal of Sociology, 101(1), 44-99.

Majchrzak A., Cooper L. P., Neece O E., 2004, Knowledge reuse for innovation, Management Science,50 ( 2), 174-188. 
MoD, 2001, Defence Acquisition, Policy Papers, $n^{\circ} 4$.

Molas-Gallart J., 1999, Measuring defence R\&D: a note on problems and shortcomings, Scientometrics, 45 (1), 3-16.

Molas-Gallart J., Tang P., 2006, Ownership matters: Intellectual Property, privatization and innovation, Research Policy, 35 (2), 200-212.

Mustar P., Larédo P., 2002, Innovation and research policy in France (1980-2000) or the disappearance of the Colbertist State, Research Policy, 31 (1), 55- 72.

Nesta L., Saviotti P., 2006, Firm knowledge and market value in biotechnology, Industrial and Corporate Change, 15(4), 625-652.

Papon P., 1998, Research institution in France: between the Republic of science and the nation satecrisis, Research Policy, 27 (1), 771-780.

Prencipe A., 1997, Technological Capabilities and Product Evolutionary Dynamics: a case study from the aero engine industry. Research Policy, 25, 1261-1276.

Revilla E., Sarkis J., Acosta J., 2005, Towards a knowledge management and learning taxonomy for research joint ventures, Technovation, 25, (11), 1307-1316

Ruttan V. , 2006, Is war Necessary for Economic Growth ? Military Procurement and Technology Development, Oxford University Press, New York.

Serfati C., 2001, The Adaptability of the French Armament Industry in an Era of Globalization, Industry and Innovation, 8. $\mathrm{n}^{\circ} 2$.

Serfati C., 2005, The role of defence innovation in national systems of innovation: an assessment based on the French Case, Woking paper presented to GREDEG seminar, April 2005.

Stowsky J., 2004, Secrets to shield or share ? New dilemmas for military R\&D policy in the digital age, Research Policy, 33, 257-269.

Teece, D., 1998, Capturing value from knowledge assets, California Management Review, 40(3), 5579.

Versailles D. , 2003, Le concept de base technologique et industrielle de Défense BTID : époques, approches acteurs -The concept of the industrial and technological basis related to defence: approaches, actors and periods-, in Versailles D., Mérindol V., Cardot P., La recherche et la technologie, enjeux de puissance, Economica, Paris pp 122-131.

Zollo, M., Winter, S.G., 2002, Deliberate Learning and the Evolution of Dynamic Capabilities, Organization Science, 13 (3), 339-351. 
List of tables:

Table 1 Average value of the structural variables 1998-2000

\begin{tabular}{cccccc}
\hline \hline & $\begin{array}{c}\text { Number of } \\
\text { firms }\end{array}$ & $\begin{array}{c}\text { Turnover } \\
€ 000 \mathrm{~s}\end{array}$ & Employees & $\begin{array}{c}\text { R\&D } \\
\text { Employees }\end{array}$ & Researchers \\
\hline B0 & $\sim 3300$ & 198033 & 973 & 58 & 25 \\
B1 & $\sim 1000$ & 396704 & 1689 & 126 & 50 \\
B2 & $\sim 100$ & 742553 & 3874 & 510 & 232 \\
\hline \hline
\end{tabular}

Source: SANDIE and R\&D surveys 1998-2000.

Table 2: R\&D expenses in non-defence and defence related firms

\begin{tabular}{cccc}
\hline \hline & DIRD & DERD & Total \\
000s€ & 000s€ & R\&D/Turnover \\
\hline B0 & 5896 & 1489 & $3.8 \%$ \\
B1 & 12634 & 3129 & $4 \%$ \\
B2 & 57925 & 17721 & $10.7 \%$ \\
\hline
\end{tabular}

Source: SANDIE and R\&D surveys 1998-2000. 
Table 3: KM practices according to sample (\%)

\begin{tabular}{lllllll}
\hline \hline KM1 & CIS3 & B0 & B0-B1 & B1 & B1-B2 & B2 \\
KM2 & 17.7 & 30.6 & 26 & 39 & 40 & 38 \\
KM3 & 27 & 45 & 37 & 57 & 56 & 66 \\
KM4 & 22.6 & 41.5 & 35 & 52 & 50 & 72 \\
\hline KMI=0 & 58.6 & 35 & 44 & 21 & 21.6 & 12 \\
KMI=1 & 12.8 & 15 & 14 & 16 & 17.2 & 12 \\
KMI=2 & 13.2 & 20 & 16.5 & 25 & 26 & 19 \\
KMI=3 & 9.1 & 16 & 15.5 & 18 & 16 & 36 \\
KMI=4 & 6.3 & 13 & 9.8 & 19 & 19.5 & 21 \\
\hline KMI avg & 0.9 & 1.6 & 1.3 & 2 & 1.9 & 2.4 \\
\hline Sample & 5100 & & 776 & & 487 & 63 \\
\hline
\end{tabular}

Source: SANDIE and R\&D surveys and French CIS3. 
Chart 1. Size and level of KM practice by sample

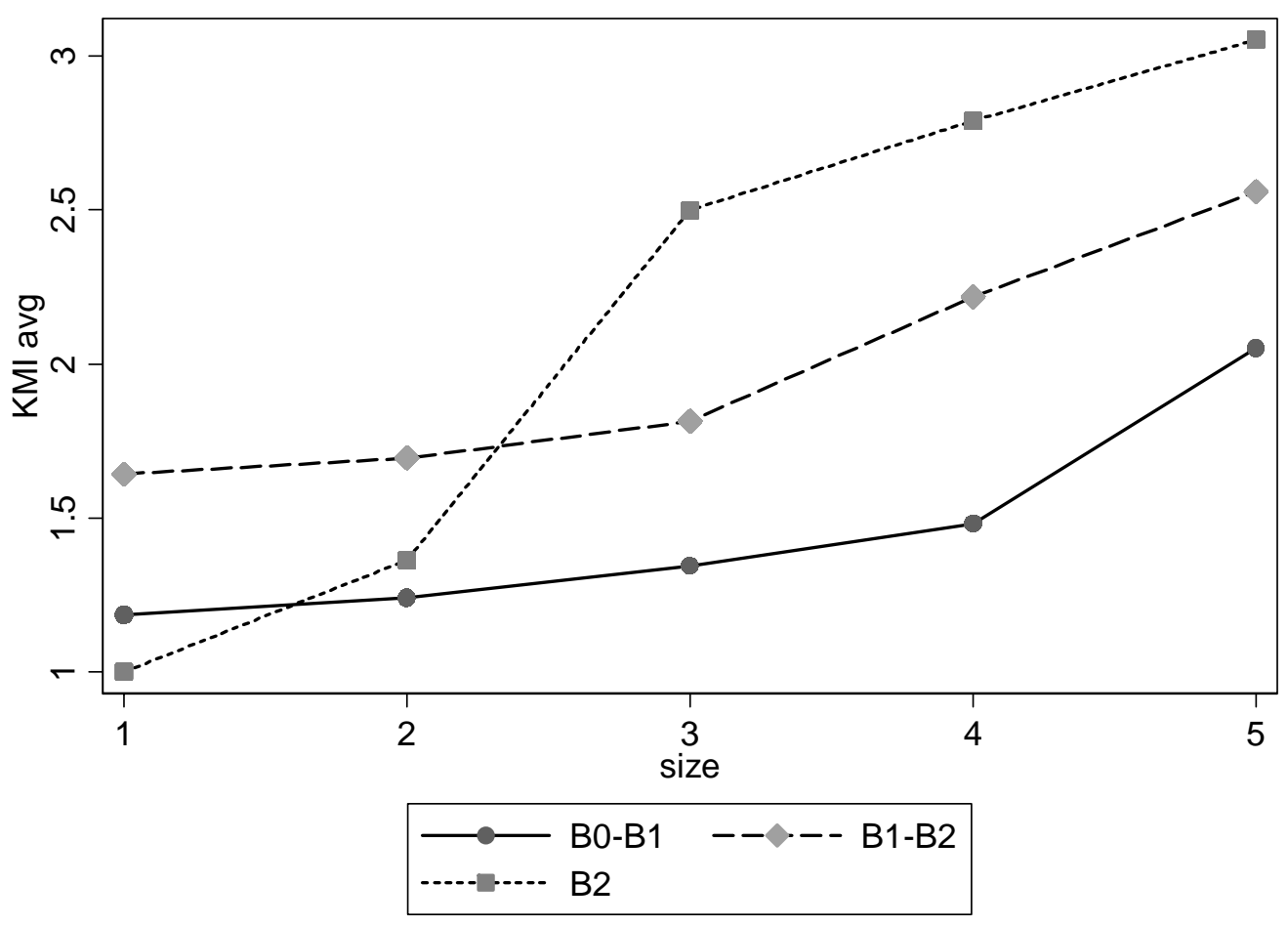

The sizes 1 to 5 are increasing sizes based on the quartiles of turnover

Source: SANDIE and R\&D surveys and CIS3 
Chart 2: Average KMI and technological intensity by sample

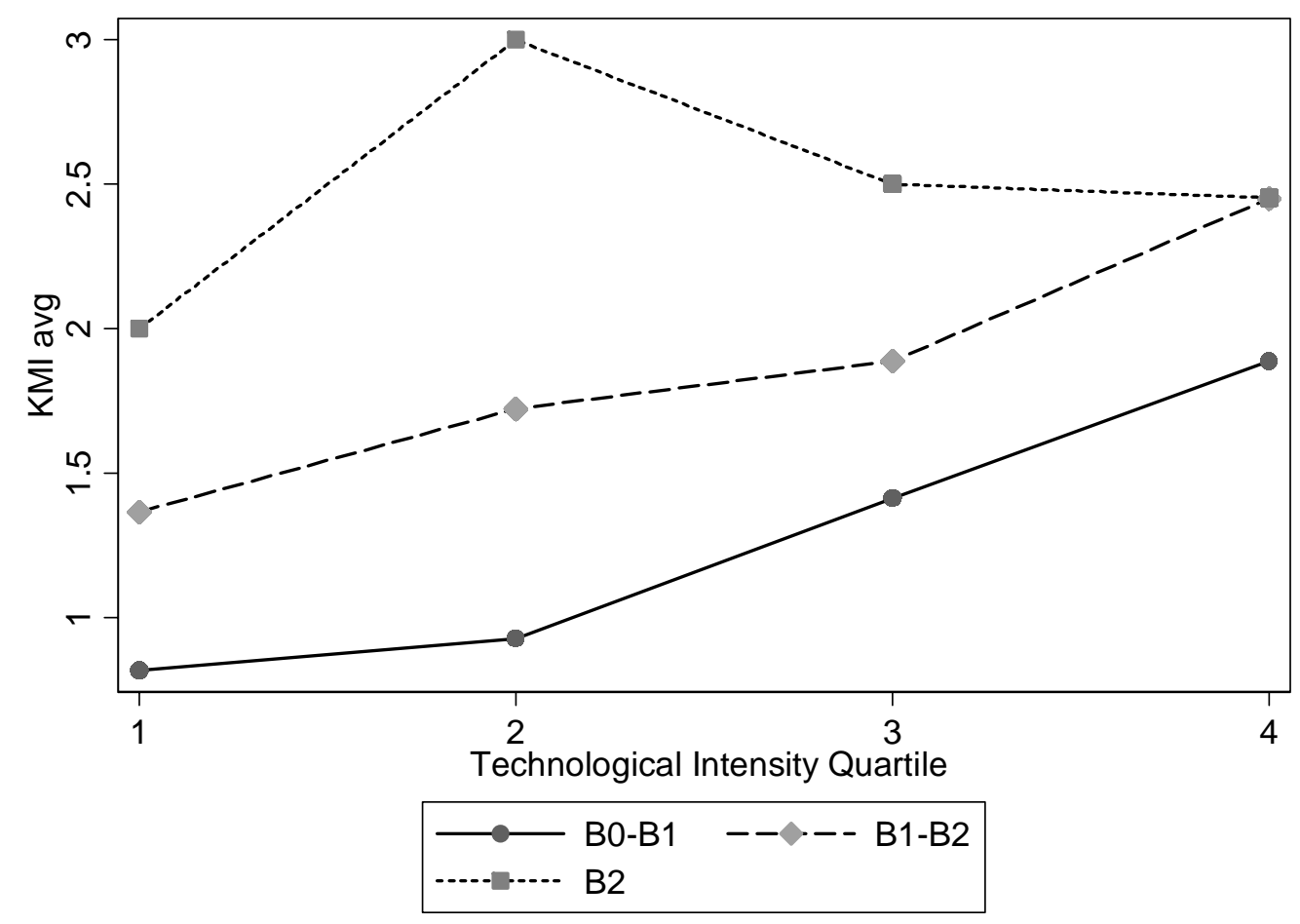

Source : SANDIE and R\&D surveys and CIS3 
Chart 3: Innovation intensity average by $\mathrm{KM}$ indicator and samples

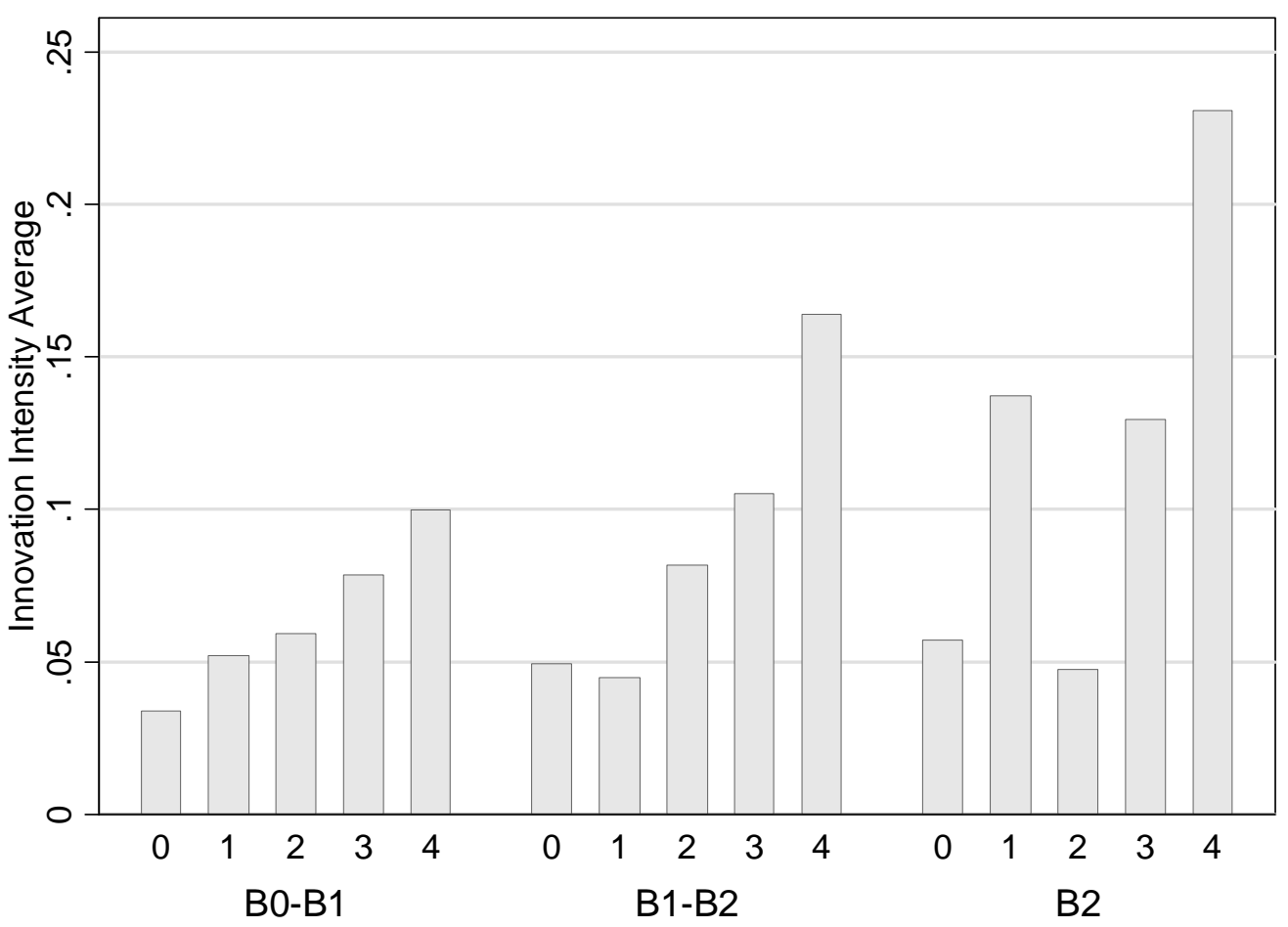

Source: SANDIE and R\&D surveys and CIS3

Chart 4: KMI average by quartiles of Innovation Intensity in B2

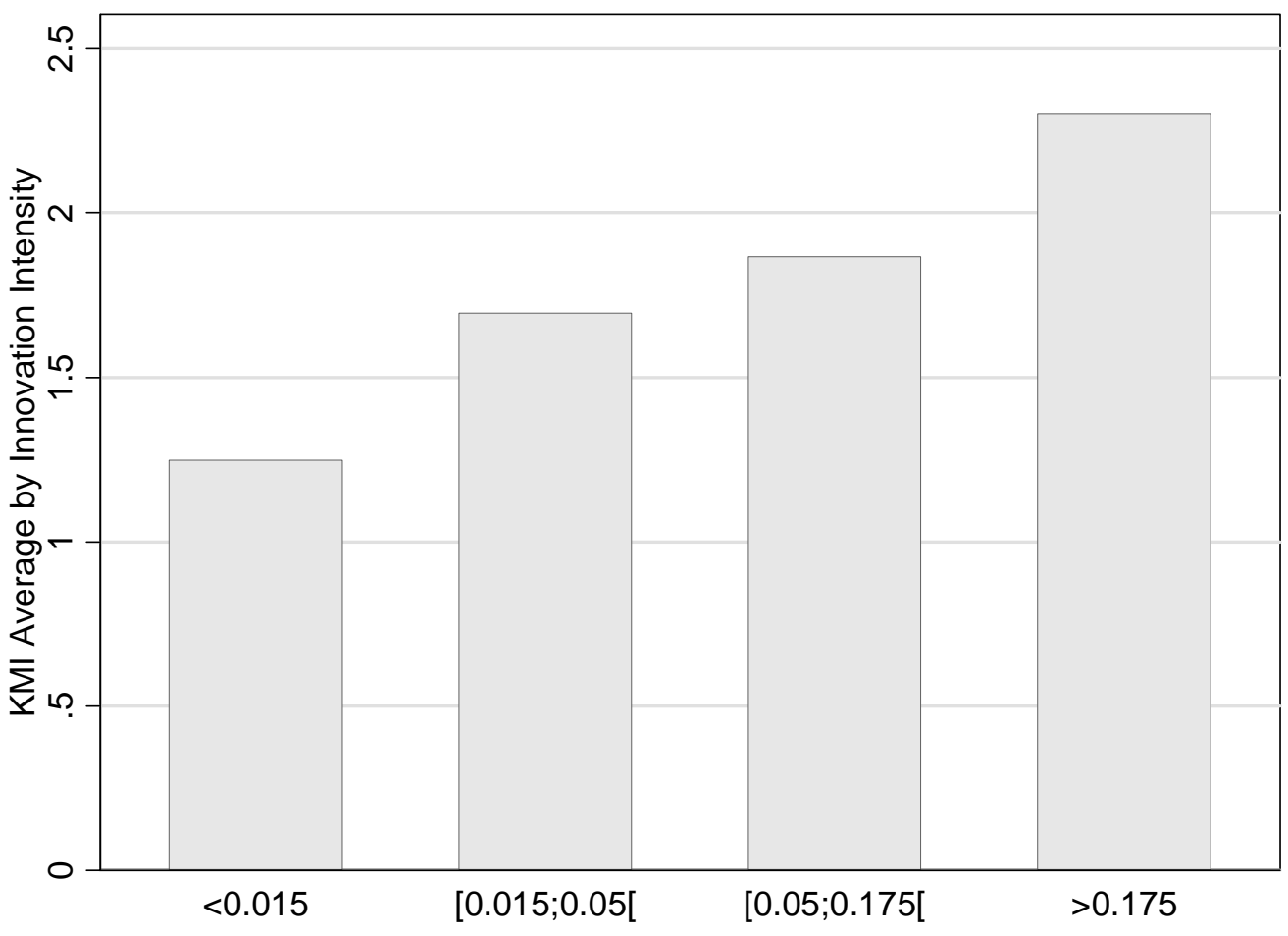

Source: SANDIE and R\&D surveys and CIS3. 
Chart 5: Average level of patent intensity and the level of KM by sample

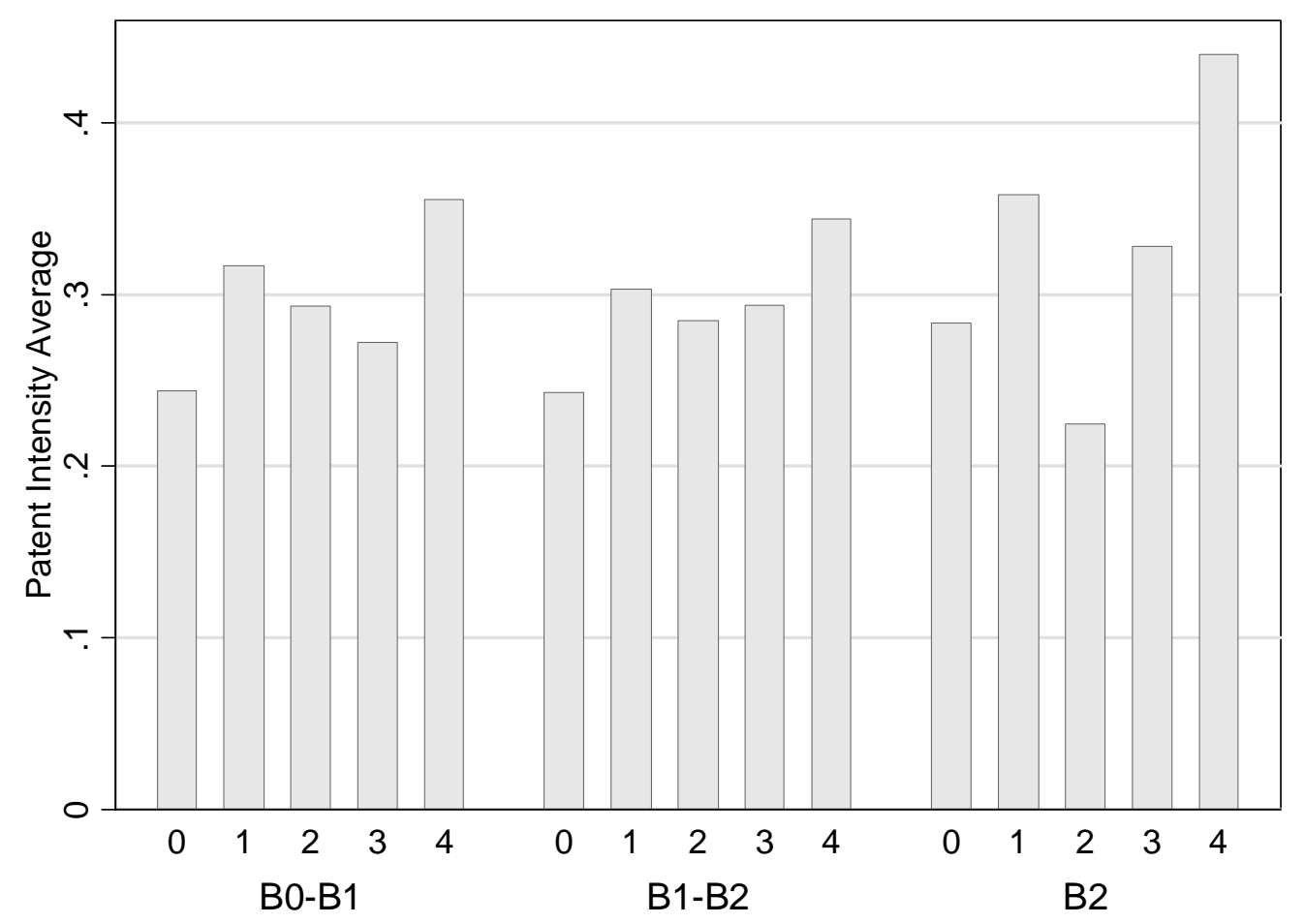

Source: SANDIE and R\&D surveys and CIS3 
Appendix 1: List of acronyms used

ANITA: ANnotation tool for Industrial TeAms

BAE : BAE Systems

CASA : Construcciones Aeronauticas S.A

CEC (Centre d'Exploitation des Connaissances) : Knowledge Exploitation Center (DAM-CEA)

CEA (Commissariat à l'Energie Atomique): French Atomic Energy Commission.

CIS: Community Innovation Survey

CoPS: Complex products and systems

COC: Centre of Competences (EADS)

CTBT: Comprehensive Test Ban Treaty

DAM (Direction des Applications Militaires): CEA's Military Applications Division.

DASA: Deutsche Aerospace GmbH

DCN (Direction des chantiers navals): Directorate for Naval Construction

DERA Defence Evaluation and Research Agency

DGA (Délégation Générale pour l’Armement) : French Armament Procurement Agency

EADS: European Aeronautic Defence and Space Company

ESA: European Space Agency

GIAT (Groupement Industriel des Armements Terrestres): France's state-owned maker of armour-plated vehicles.

LSI: Lead Systems Integrator

NIS: National Innovation System

MBB: Messerschmitt-Bölkow-Blohm GmbH

MoD: UK Ministry of Defence

MOKA: Methodology and tools Oriented to Knowledge based engineering Applications

MKSM : Method for Knowledge Systems Management

OED (Observatoire Economique de la Défense): Economic Defence Observatory belonging to the French Defence Ministry.

ONERA: French Aeronautics and Space Research Centre

SANDIE (Statistiques Annuelles sur la Défense, son Industrie et ses Entreprises) : Annual Statistics on Defence Industry and Database, realized by OED.

SNPE (Société Nationale des Poudres à explosifs) : National Company for Explosive Materials VFW: Vereinigte Flugtechnische Werke. 
Appendix 2: Qualitative interviews conducted in the French defence industry

\begin{tabular}{|c|c|c|}
\hline & $\begin{array}{l}\text { General presentation of government } \\
\text { agencies and firms interviewed }\end{array}$ & Missions \\
\hline DGA & $\begin{array}{l}\text { Direction Générale de l’Armement } \\
\text { French Armament Procurement Agency }\end{array}$ & $\begin{array}{l}\text { Management of armament programmes } \\
\text { Acquisition of arms equipment } \\
\text { Technical and scientific expertise related to equipping the defence } \\
\text { forces } \\
\text { Trials and evaluations } \\
\text { General training and support }\end{array}$ \\
\hline CEA-DAM & CEA's Military Applications Division & $\begin{array}{l}\text { Design, manufacture, maintenance and dismantling of nuclear } \\
\text { warheads } \\
\text { Design and maintenance of the nuclear reactors for the propulsion } \\
\text { of French navy vessels } \\
\text { Simulation program designed to guarantee France's nuclear } \\
\text { deterrence capability }\end{array}$ \\
\hline ONERA & $\begin{array}{l}\text { Office National d'Etudes et de } \\
\text { Recherches Aérospatiales } \\
\text { French Aeronautics and Space Research } \\
\text { Centre }\end{array}$ & $\begin{array}{l}\text { Main aerospace research organization in France, ONERA bridges } \\
\text { between scientific research and industry } \\
\text { Created in } 1946 \text { to regroup the aeronautics research teams from } \\
\text { different organizations } \\
\text { Core skills in planes, helicopters, missiles and space programmes }\end{array}$ \\
\hline THALES & $\begin{array}{l}\text { Electronic systems and industrial } \\
\text { electronics group, acting in defence, } \\
\text { aerospace, airline security and safety, } \\
\text { information }\end{array}$ & $\begin{array}{l}\text { Main focus is on dual technologies with significant potential in all } \\
\text { three business areas: Aerospace, Defence and Security } \\
\text { Technological research is aimed at reducing the costs of } \\
\text { increasingly complex products ands systems through innovative } \\
\text { tools and software projects }\end{array}$ \\
\hline EADS & $\begin{array}{l}\text { European Aeronautic Defence and Space } \\
\text { Company (EADS) }\end{array}$ & $\begin{array}{l}\text { Main focus on civil aeronautics, defence technology, helicopters, } \\
\text { space, missiles, military transport, combat aircraft and services. } \\
\text { EADS Group includes the Airbus, Eurocopter and Astrium } \\
\text { Companies. }\end{array}$ \\
\hline
\end{tabular}


${ }^{\mathrm{i}}$ Generally the defence industry is defined by the characteristics of its products or services. For a discussion, see Dowdall (2004: 538) who emphasizes the practical difficulty of applying this concept to a multi products organization context. The scope of this industry is broad and rarely confined to strict defence products, but can include field like such telecommunications, hydroelectric and nuclear power, public utilities, etc.... For this reason, in this article, 'defence industry' includes all those firms that are direct suppliers of Defence Ministry and implement R\&D (see section 2 for details). This definition allows for the fact that 'governments are central to understanding defence industries’ (Hartley 2001, in Hartley and Sandler (eds); see also Hartley 2006).

${ }^{\text {ii }}$ Guarantee of nuclear weapons reliability and safety is one of key requirement to maintain the capability of the French deterrents. Cessation of nuclear testing CTBT (signature approved by France, UK in 1998, and Russia in 2000) leads to a redefinition of the roadmap to achieve such a goal. In this context, CEA-DAM proposed another strategy to preserve knowledge concerning nuclear weapons, with the implementation of the Simulation Program. The problems related to knowledge losses in the nuclear industry due to the interruption to nuclear testing, are general and have affected other countries as well as France (Gusterson 1992; MacKenzie and Spinardi 1995)

iii This knowledge policy was driven by the military needs of the department for the construction of nuclear weapons (DAM).

${ }^{i v}$ In the defence industry, the aging workforce is a reality that cannot be ignored (Agostino, Guitton (Céreq) 2007). Indeed, it is estimated that half the workforce in this industry - including rank 1 and rank 2 subcontractors - will retire between 2000 and 2015. Knowledge preservation, renewal and transfer are therefore crucial issues.

${ }^{v}$ At the end of 2002, 271 experts were identified and almost 220 have transferred their knowledge via various means, including:

1) $60 \%$ by video (apparently the most practical tool to record knowledge in CEC, and also a means of capturing tacit knowledge. E.g., through watching the videos, it was discovered that technicians systematically carried tools around rather than over the nuclear weapon in order to avoid accidentally dropping anything on the bomb and possibly setting it off. This very simple measure was implemented by the employees themselves for security reasons, although it was not included in the official 'check list' concerning the building of nuclear weapons;

2) $15 \%$ through interviews (with MKSM);

3) $20 \%$ through written monographs and reports;

4) $5 \%$ through conferences.

vi Engineers and researchers often worked in a purely 'empiricist' manner, relying on tests to improve their knowledge. This approach has been reversed gradually, and the current aim is to analyse and codify crucial knowledge. This has required the development of models for the construction of nuclear weapons, which has reduced levels of uncertainty and increased the reliability of weapons. This codification led the firms to reconsider the design of nuclear weapons in order to create more reliable and robust designs. This means that in the absence of direct validation through practice, the design has to be tested by models in order to decrease the level of uncertainty. In this regard, codification implies a degree of simplification such that the reliability of the weapons designed can increase.

${ }^{\text {vii }}$ The MKSM was elaborated in CEA by J.L. Ermine. For a longer discussion on CEA KM policy see Lazaric, et al. (2004).

viii By eliminating, e.g., certain sophisticated technical features the military usefulness of which was not established during the specification process, and by making more use of existing civil technologies.

ix This renewed concentration on manufacturing is also due to the fact that a large number of programmes reached their production phase between 1995 and 2005.

${ }^{x}$ This transfer of knowledge is not new. Indeed, the activities related to explosives have been outsourced; the SNPE and the GIAT were created in 1991 and the DCN in 2003. At the technological level, the privatization of shipyard activities was followed by the transfer of knowledge from the DGA to Thales, particularly in the strategic domain of radar. DCN was one of the operational directorates of the DGA. In April 2007, DCN became DCNS. This followed an agreement in which Thales became a $25 \%$ shareholder in the new company. 
${ }^{\mathrm{xi}}$ Via a database of in use and abandoned patents.

${ }^{\text {xii }}$ Via the identification of experts and inventors.

xiii E.g., one outcome concerning ICT tools implementation is due to European collaboration in the framework of the MOKA (Methodology and tools Oriented to Knowledge based engineering Applications) consortium. The objective of MOKA was to codify some part of the knowledge in a simulation programme such as Esprit, involving MBB, PSA, BAE, and other companies. This network, which has been successful, is still in operation working via its web site despite the programme ending in 2000, which reflects the intense collaboration of network members. EADS is also working with the ESA (European Space Agency). This collaboration has led to a considerable reduction in the calculation of the time involved in launch trajectories through the use of specific algorithms. However, despite significant time saving (from 3 months of preparation to 1 day), the method has not been widely diffused. This is because it disrupts many habits and daily routines, and is not considered sufficiently reliable. It is considered experimental and requires further development.

xiv This tool has opened up opportunities to combine existing content with various other ideas and is a first step towards the real integration of knowledge. To date, only small communities of industrial researchers have participated in ontology building enabled by the ANITA tool. In order for it to diffuse in diverse networks, the ontology needs to be enlarged and enriched. This became apparent when attempts were made to introduce ANITA in a German research centre, resulting in problems that have yet to be resolved, which demonstrates the difficulties involved in and the limitations of this KM policy.

${ }^{\mathrm{xv}}$ SANDIE (Statistiques Annuelles sur la Défense, son Industrie et ses Entreprises) is a database of annual statistics on the French Defence Industry. It is produced and maintained by OED and includes suppliers to the Defence Ministry (more than 12,000 firms) over the period 1998-2000. SANDIE is a filter that allows identification of firms with trade relationships with the Defence Ministry.

${ }^{x v i}$ In French this survey is known as «Enquêtes Annuelles sur les Moyens consacrés à la Recherche et au Développement dans les Entreprises » -Annual survey of R\&D expenses and related means. This survey is implemented by the French Ministry of Research and Education and is a quasi exhaustive and representative survey of firms involved in R\&D. 